\title{
PENGARUH PERSEPSI MAHASISWA AKAN MINAT, MOTIVASI, PELATIHAN PROFESIONAL, GENDER DAN LINGKUNGAN PEKERJAAN TERHADAP PILIHAN KARIR AKUNTAN PUBLIK DAN NON PUBLIK
}

(Study Empiris Mahasiswa Akuntansi pada Universitas Buddhi dan Muhammadiyah yang berada di Wilayah Tangerang Periode 2015/2016)

\author{
THE EFFECT OF STUDENTS PERCEPTION FOR INTEREST, \\ MOTIVATION, PROFESSIONAL EDUCATION, GENDER, AND WORKING \\ ENVIRONMENT FOR CAREER SELECTION AS PUBLIC AND NON-PUBLIC \\ ACCOUNTING \\ (An Empirical Study of Accounting Students at Buddhi and Muhammadiyah \\ University in Tangerang Region 2015/2016 Period)
}

\author{
Agung Joni Saputra \\ Prodi Akuntansi Universitas Universal, Batam, Indonesia \\ agungjs13@gmail.com
}

\begin{abstract}
Abstrak
Penelitian ini bertujuan untuk menganalisis pengaruh persepsi mahasiswa akuntansi akan minat, motivasi, pelatihan professional, gender, dan lingkungan pekerjaan terhadap pilihan karir akuntan publik dan non publik. Penelitian ini menggunakan data primer yang diperoleh dengan menyebarkan kuisioner kepada para mahasiswa akuntansi yang berada di universitassBuddhi Dharma dan universitas Muhammadiyah Tangerang. Metode analisis untuk menguji hipotesis adalah analisis regresi linier berganda. Hasil penelitian ini menunjukan secara simultan bahwa minat, motivasi, pelatihan professional, gender, dan lingkungan pekerjaan terhadap pilihan karir akuntan publik dan non publik. Sedangkan secara parsial hanya variabel gender dan variabel lingkungan pekerjaan yang berpengaruh terhadap pilihan karir akuntan publik dan non publik, sedangkan variabel minat, motivasi, dan pelatihan profesional tidak berpengaruh terhadap pilihan karir akuntan publik dan non publik.
\end{abstract}

Kata kunci : minat, motivasi, pelatihan professional, gender, lingkungan pekerjaan, pilihan karir akuntan publik dan non publik

\begin{abstract}
This study aims to analyze the effect of accounting students' perceptions of interest, motivation, professional training, gender, and work environment on their career choices of public and non-public accountants. This study uses primary data collected by distributing questionnaires to accounting students of Buddhi Dharma University and Muhammadiyah University of Tangerang. The analytical methods to test the hypotheses is multiple linear regression analysis. The results of this study show simultaneously that interest, motivation, professional education, gender, and work environment has a significant effect for selection career of public and non-public accountant. While partially only gender variables and work environment variables that influence the career choices of public and non-public accountants, whereas the variables of interest, motivation, and professional training do not affect the career choices of public and non-public accountants.
\end{abstract}

Keyword: interest, motivation, professional education, gender, working environment, career selection for public and non public accountant 


\section{PENDAHULUAN}

Pilihan karir merupakan sesuatu proses atau aktivitas individu dalam usaha mempersiapkan diri untuk memasuki karir yang berhubungan dengan pekerjaan melalui suatu rangkaian proses kegiatan yang terarah dan sistematis, sehingga mampu memilih karir sesuai dengan yang diinginkan. Dalam membuat pilihan karir terlebih dahulu seseorang mencari mengenai berbagai macam alternatif profesi.

Perkembangan dunia bisnis harus direspon oleh sistem pendidikan akuntansi

yang berkualitas dan siap pakai didunia kerja. Agar dapat mencapai tujuan tersebut maka desain pendidikan akuntansi harus relevan dengan dunia kerja bagi sarjana akuntansi. Berbagai jenis karir yang dapat ditekuni oleh sarjana akuntansi menunjukan bahwa setiap sarjana akuntansi bebas untuk memilih karir apa yang akan dijalaninya (Rahayu, 2011)

Akuntan publik atau auditor adalah akuntan yang bekerja dikantor akuntan publik. Jenis pekerjaan yang dapat dilakukan oleh kantor akuntan publik adalah pemeriksaan laporan keuangan dan konsultasi dibidang keuangan. Jenis pekerjaan tersebut mencerminkan seorang akuntan yang bekerja di kantor akuntan publik akan selalu berhubungan dengan klien, yaitu perusahaan yang meminta jasa kantor akuntan publik (Wijayanti, 2003). (Jumamik, 2007) menyatakan bahwa akuntan publik adalah akuntan yang bergerak dalam bidang akuntansi publik, yaitu menyerahkan berbagai macam jasa akuntansi untuk perusahaan-perusahaan bisnis. Akuntan publik merupakan satu-satunya profesi yang berhak memberikan opini atas kewajaran dari laporan keuangan yang disusun manajemen.

Akuntan perusahaan atau auditor intern adalah auditor yang bekerja dalam perusahan (perusahaan Negara maupun perusahaan swasta) yang tugas pokoknya adalah menentukan apakah kebijakan dan prosedur yang ditetapkan oleh manajemen puncak telah dipatuhi, menentukan baik atau tidaknya penjagaan terhadap kekayaan organisasi menentukan efisiensi dan efektivitas prosedur kegiatan organisasi, serta menentukan keandalan informasi yang dihasilkan oleh berbagai bagian organisasi (Trirorania,2004).

(Wijayanti, 2003) mengungkapkan bahwa mahasiswa beranggapan bekerja sebagai akuntan perusahaan lebih memberikan kepastian masa depan dengan adanya dana pension dan sifat pekerjaan yang rutin. (Wijayanti, 2003) juga mengungkapkan bahwa mahasiswa akuntansi lebih senang berprofesi diperusahaan nasional daripada perusahaan lokal, karena perusahaan nasional lebih dikenal daripada perusahaan lokal sehingga dapat diperkirakan segi baik maupun buruk nya suatu perusahaan. Hal tersebut mempunyai implikasi bahwa posisi kerja diperusahaan nasional merupakan factor penting dalam mempertimbangkan pemilihan profesi.

(Sri Rahayu, Eko Arief S, 2003) mengatakan bahwa mahasiswa yang mengharapkan bekerja sebagai akuntan pendidik lebih mempunyai jaminan hari tua. Temuan inilah yang menjadi pengharapan mahasiswa jurusan akuntansi untuk termotivasi memilih profesi akuntan pendidik. (Jumamik, 2007) menambahkan bahwa akuntan pendidik merupakan profesi yang menghasilkan sumber daya manusia yang berkarir pada tiga bidang akuntan lainnya. Akuntan pendidik melaksanakan proses penciptaan professional, baik profesi akuntan publik, akuntan perusahaan, dan akuntan pemerintah. Seiring dengan perkembangan perekonomian yang pesar, maka dibutuhkan akuntan yang semakin banyak pula. Dalam konteks permasalah inilah diperlukan pemenuhan kebutuhan akan tenaga akuntan pendidik.

(Jumamik, 2007) menyatakan bahwa akuntan pemerintah adalah akuntan yang bekerja pada instansi pemerintah yang tugas pokoknya melakukan pemeriksaan terhadap pertanggungjawaban keuangan yang ditunjuk oleh unit-unit organisasi dalam pemerintahan atau pertanggungjawaban keuangan yang ditunjuk kepada pemerintah. Meskipun terdapat banyak akuntan yang bekerja diinstansi pemerintah, namun Departemen Keuangan, Badan Pengawasan Keuangan dan Pembangunan (BPKP) dan Badan Pemeriksa Keuangan (BPK) dan instansi pajak adalah instansi pemerintah yang bertanggungjawab kepada Presiden 
Republik Indonesia dalam bidang pengawasan keuangan dan pembangunan yang dilakukan oleh pemerintah bukan oleh akuntan pemerintah.

\title{
Hipotesis
}

Model deskriptif hipotesis secara parsial adalah :

\section{Hipotesis 1}

$\mathbf{H a}_{1}$ : Terdapat pengaruh minat terhadap pilihan karir akuntan publik dan non publik

\author{
Hipotesis 2 \\ $\mathbf{H a}_{2}$ : Terdapat pengaruh motivasi terhadap pilihan karir akuntan publik dan non \\ publik
}

\section{Hipotesis 3}

$\mathbf{H a}_{3}$ : Terdapat pengaruh pelatihan profesional terhadap pilihan karir akuntan publik dan non publik

\section{Hipotesis 4}

$\mathbf{H a}_{4}$ : Terdapat pengaruh gender terhadap pilihan karir akuntan publik dan non publik

\section{Hipotesis 5}

$\mathbf{H a}_{5}$ : Terdapat pengaruh lingkungan pekerjaan terhadap pilihan karir akuntan publik dan non publik

Model deskriptif hipotesis secara simultan :

\section{Hipotesis 6}

$\mathbf{H a}_{\mathbf{6}}$ : Ada pengaruh persepsi mahasiswa secara simultan akan minat, motivasi, pelatihan professional, gender, dan lingkungan pekerjaan terhadap pilihan karir akuntan publik dan non publik

\section{Kerangka Pemikiran}

Penelitian ini difokuskan pada Pengaruh persepsi mahasiswa akuntansi akan minat, motivasi, pelatihan professional, gender, dan lingkungan pekerjaan terhadap pilihan karir akuntan publik dan non publik, dimana kerangka penelitian ini menunjukan pengaruh secara parsial dan simultan antara masing-masing variabel independen yang terdiri dari minat (X1), motivasi (X2), pelatihan profesional (X3), gender (X4), dan lingkungan pekerjaan (X5) terhadap variabel dependen yaitu pilihan karir akuntan publik dan non publik (Y).

\section{Kajian Teori}

Menurut (Gunawan, Aprilia., 2014) Persepsi dapat diartikan sebagai suatu proses perjalanan sejak dikenalnya suatu objek melalui organ organ indera sampai diperolehnya gambaran yang jelas dan dapat dimengerti serta diterma objek tersebut dalam kesadaran kita. Proses persepsi dimulai dari diterimanya rangsangan (stimulasi) oleh seseorang melalui alat penerimanya (panca indera), dilanjutkan ke pusat susunan syaraf yaitu otak, rangsangan tersebut kemudian diinterpretasikan sehingga individu menyadari, mengerti, dan memahami apa yang diinderanya itu. Sedangkan menurut (Stephen P. Robbins, 2009: 175).

Minat dapat diartikan sebagai "Kecenderungan yang tinggi terhadap sesuatu, tertarik, perhatian, gairah dan keinginan". Pendapat lain tentang pengertian minat yaitu "Kesadaran seseorang bahwa suatu objek, seseorang, suatu soal maupun situasi yang mengandung sangkut paut dengan dirinya. (Sandjaja, B., Heriyanto, 2006:32). 
(Slameto, 2003:57) minat adalah "Kecenderungan yang tetap untuk memperhatikan dan mengenang beberapa kegiatan". Kegiatan yang diminati seseorang diperhatikan terusmeneruts yang disertai dengan rasa senang. Sedangkan menurut Holland yang dikutip oleh (Djaali, 2007 : 32) mengatakan bahwa "Minat adalah kecenderungan hati yang tinggi terhadap sesuatu".

(Siagian, 2008) menyatakan bahwa motivasi memiliki arti keseluruhan proses pemberian motivasi bekerja kepada bawahan sedemikian rupa sehingga mereka mau bekerja dengan iklas demi tercapainya tujuan organisasi dengan efisien dan ekonimis.

Pelatihan professional meliputi hal-hal yang berhubungan dengan peningkatan keahlian. Pelatihan professional diuji dengan empat pernyataan mengenai pelatihan sebelum mulai bekerja, pelatihan professional, pelatihan kerja rutin dan pengalaman kerja (Rahayu, 2011). (Rivai, 2004) menyatakan pelatihan dan pengakuan profesional termasuk faktor penghargaan non finansial. Perbedaan tersebut akan dilihat karena kemungkinan antara satu jenis pofesi dengan jenih profesi yang lain memberikan penghargaan non finansial ini dengan cara yang berbeda.

Kultur masyarakat pada era sebelum kartini yang melarang wanita untuk bekerja pada saat ini sudah sangat jauh dari persepsi masyarakat, wanita sekarang sudah dianggap memiliki peran dan berkarya dalam seluruh aspek kehidupan sosial,

Gender adalah pembagian peran, kedudukan, dan tugas antara laki-laki dan perempuan yang ditetapkan oleh masyarakat berdasarkan sifat perempuan dan laki-laki yang dianggap pantas menurut norma-norma, adat istiadat, kepercayaan, atau kebiasaan masyarakat.

Lingkungan kerja sangat mendukung dalam memilih karir, lingkungan kerja yang aman dan menyenangkan dapat meningkatkan prestasi karyawan. Lingkungan kerja berkaitan dengan tipe pekerjaan dan lingkungan tempat bekerja. (Andersen, 2012) menyatakan lingkungan kerja merupakan suasana kerja yang meliputi sifat kerja (rutin, atraktif dan itentitas jam lembur), tingkat persaingan antar karyawan dan tekanan kerja merupakan factor dari lingkungan pekerjaan. Karakter yang keras dan komitmen dibutuhkan oleh seorang akuntan dalam menghadapi lingkungan pekerjaan, seorang pekerja dituntut untuk dapat beradaptasi dan bersosialisasi dengan lingkungan kerja, agar dapat mencapai targer kerja yang diwajibkan. Oleh sebab itu lingkungan kerja sangat dipertimbangkan karena menyangkut kenyamanan kerja nantinya jika menekuni suatu karir.

\section{Teori Pendukung}

Teori pengharapan, teori ini menyatakan bahwa intensitas kecenderungan untuk melakukan dengan cara tertentu pada intensitas harapan bahwa kinerja akan diikuti dengan hasil yang pasti dan hasil kepada individu. Menurut (Stephen P. Robbins, Timothy A. Judge, 2009) pengharapan akan mempengaruhi sikap seseorang dan sikap tersebut terbentuk dari tiga komponen, yaitu : 1. Cognitive component, merupakan keyakinan dari informasi yang dimiliki oleh seseorang yang akan mempengaruhi sikap seseorang terhadap profesi yang akan di jalani, 2. Emotional component merupakan perasaan yang bersifat emosi yang dimiliki oleh seseorang untuk menyukai sesuatu, dan 3. Behavior component kegiatan untuk bertindak secara lebih khusus dalam merespon kejadian dan informasi dari luar, sehingga seseorang akan termotivasi untuk menjalankan tingkat usaha yang tinggi apabila ia meyakini bahwa upaya tersebut akan menghantarkannya kesuatu kinerja yang lebih baik. Dengan mengetahui informasi yang dimiliki oleh suatu profesi dan didukung oleh rasa suka dan terpenuhnya pengharapan yang diinginkan akan memotivasi seseorang dalam memilih profesi yang akan dijalaninya.

Teori hirarki atau teori kebutuhan dasar, untuk memenuhi kebutuhan hidup merupakan suatu alas an utama seorang individu untuk berkarir, oleh sebab itu terdapat faktor-faktor yang berperan sebagai pemuas kebutuhan sehingga dipertimbangkan oleh seorang individu dalam memilih karir yang akan dijalaninya. Hirarki kebutuhan Maslow (Stephen P. Robbins, 
Timothy A. Judge, 2011) menyatakan bahwa didalam setiap individu ada suatu jenjang untuk lima kebutuhan : 1. Kebutuhan fisiologis yang melipiti sandang, pangan dan papan, 2. Kebutuhan keamanan yang meliputi perlindungan fisik dan emosional, 3. Kebutuhan sosial yang meliputi kasih sayang, rasa dimiliki, dan persahabatan, 4. Penghargaan yang meliputi harga diri, otonomi, prestasi, status, pengakuan, dan perhatian, 5. Aktualisasi diri yang meliputi pencapaian potensi diri dan pemenuhan diri.

\section{METODE}

Penelitian ini berupa penelitian primer dimana data yang diambil berupa data quisioner, penelitian ini menggunakan convenience sampling, yaitu pengambilan sampel berdasarkan kemudahan dan menyebarkan quisioner sebanyak 76 kuisioner ke universitas Budhi Dharma namun hanya diambil sebanyak 70 sample yang dapat diuji dan 102 kuisioner ke universitas Muhammadiyah namun hanya bisa di olah sebanyak 92 penyebaran ke universitas yang berada diwilayah Tangerang, dan mengolah data dengan menggunakan uji validitas dan realibilitas, serta uji asumsi klasik yang terdiri dari uji normalitas, uji heteroskedastisitas, dan uji multikolinearitas.

\section{HASIL DAN PEMBAHASAN}

Hasil regresi yang diperoleh dengan menggunakan SPSS ver 20 :

$$
\begin{gathered}
\text { Persamaan Regresi : } \\
Y=\alpha+\beta_{1} X_{1}+\beta_{2} X_{2}+\beta_{3} X_{3}+\beta_{4} X_{4}+\beta_{5} X_{5}+E
\end{gathered}
$$

Peneliti menyertakan lembar identitas diri responden disetiap rangkap kuisioner yang terdiri dari :
a. Jenis Kelamin
: Jenis kelamin responden (pria/wanita)
b. Usia
c. Universitas
: Usia responden
: Universitas yang digunakan sebagai populasi dan sampel
(Buddhi Dharma dan Muhammadiyah)
d. Profesi yang diinginkan : Meliputi profesi yang ingin didapat (akuntan publik, akuntan pendidik, akuntan pemerintah, atau akuntan perusahaan).

Berdasarkan data jenis kelamin, dapat diketahui bahwa sebanyak 75 responden $(46,3 \%)$ adalah pria, dan sisanya sebanyak 87 responden $(53,7 \%)$ adalah wanita.

Berdasarkan data usia responden, dapat diketahui bahwa sebanyak 26 responden (16\%) berusia 20 tahun, 70 responden $(43,2 \%)$ berusia 21 tahun. 42 responden $(25,9 \%)$ berusia 22 tahun, dan 24 responden $(14,8 \%)$ berusia 23 tahun.

Berdasarkan data universitas, dapat diketahui sebanyak 70 responden $(43,2 \%)$ berasal dari universitas Buddhi Dharma dan sebanyak 92 responden $(56,8 \%)$ berasar dari universitas Muhammadiyah.

Berdasarkan data profesi yang diinginkan responden, dapat diketahui sebanyak 31 responden $(19,1 \%)$ memilih akuntan publik sebagai profesinya, 38 responden $(23,5 \%)$ memilih akuntan pemerintah sebagai profesinya, 42 responden $(25,9 \%)$ memilih akuntan pendidik sebagai profesinya, dan 51 responden $(31,5 \%)$ memilih akuntan perusahaan sebagai profesinya.

Pengujian dilakukan dengan menggunakan korelasi produk Moment Pearson. Masingmasing skor pernyataan dikorelasikan dengan skor total dalam satu variabel, metode ini menyatakan suatu pernyataan adalah valid apabila. Suatu variabel dikatakan valid apabila nilai r-hitung yang merupakan nilai dari Correlated Item Correlation > dari r-tabel (n-k), alpha yang dipergunakan dalam penelitian ini adalah $5 \%$. 
Keterangan :

$\mathrm{n} \quad$ : Jumlah responden

$\mathrm{k} \quad$ : Jumlah pertanyaan

Jumlah responden sebanyak 162 responden dan variabel x1 memiliki 3 pertanyaan, x2 memiliki 5 pertanyaan, $x 3$ memiliki 4 pertanyaan, $x 4$ memiliki 8 pertanyaan, $x 5$ memiliki 4 pertanyaan, dan y memiliki 6 pertanyaan. Maka $r$ tabel untuk validitas $x 1$ menggunakan $(162-3=159) 0,156, x 2$ menggunakan $(162-5=157) 0,157, x 3$ menggunakan $(162-4=158)$ 0,156 , x4 menggunakan $(162-8=154) 0,158$, x5 menggunakan $(162-4=158) 0,156$, dan variabel y menggunakan $(162-6=156) 0,157$.

Setelah data yang diuji dinyatakan valid dan reliable, data tersebut dapat langsung digunakan untuk analisis atau pengolahan data selanjutnya yaitu regresi logistic. Untuk melakukan pengolahan data regresi dan analisis jalur, maka data yang dimiliki minimal merupakan data interval. Transformasi data ordinal yang dimiliki menjadi data interval dapat dilakukan dengan menggunakan prosedur MSI (Method of Successive Interval) dengan bantuan Excel. karena tidak semua program excel mempunyai program tambahan perhitungan MSI, maka program ini harus didownload terlebih dahulu di Internet melalui Google Search, nama file MSI nya adalah stat97.xla. setelah transformasi data maka hasil data transformasi tersebut dapat digunakan untuk menguji asumsi klasik

Berdasarkan data, dapat diketahui bahwa jawaban responden variabel X1 (Minat) mempunyai skor minimum 4.03 dan skor maximum 12,22 , rata-rata 8,5384, standar deviasi 2,02166. Standar deviasi merupakan suatu ukuran penyimpangan. Jika nilainya kecil maka data yang diguanakan mengelompok disekitar nilai rata-rata, nilai variance 4.087 yang berarti tingkat penyebaran data normal, atau data sangat heterogen.

Berdasarkan data, dapat diketahui bahwa jawaban responden variabel X2 (Motivasi) mempunyai skor minimum 9,42 dan skor maximum 21,15 , rata-rata 15,3220, standar deviasi 3,07052. Standar deviasi merupakan suatu ukuran penyimpangan. Jika nilainya kecil maka data yang digunakan mengelompok disekitar nilai rata-rata, nilai variance 9,428 yang berarti tingkat penyebaran data normal, atau data sangat heterogen.

Berdasarkan data, dapat diketahui bahwa jawaban responden variabel X3 (Pelatihan Profesional) mempunyai skor minimum 4,00 dan skor maximum 16,31, rata-rata 11,1062, standar deviasi 2,76274. Standar deviasi merupakan suatu ukuran penyimpangan. Jika nilainya kecil maka data yang digunakan mengelompok disekitar nilai rata-rata, nilai variance 7,633 yang berarti tingkat penyebaran data normal, atau data sangat heterogen.

Berdasarkan data, dapat diketahui bahwa jawaban responden variabel X4 (Gender) mempunyai skor minimum 7,81 dan skor maximum 27,23 , rata-rata 17,8735 , standar deviasi 3,84653 . Nilai variance 14,796 yang berarti tingkat penyebaran data normal, atau data sangat heterogen.

Berdasarkan data diatas, dapat diketahui bahwa jawaban responden variabel X5 (Lingkungan Pekerjaan) mempunyai skor minimum 4,00 dan skor maximum 12,28, rata-rata 8,2332, standar deviasi 2,61039. Standar deviasi merupakan suatu ukuran penyimpangan. Jika nilainya kecil maka data yang diguanakan mengelompok disekitar nilai rata-rata, nilai variance 6,814 yang berarti tingkat penyebaran data normal, atau data sangat heterogen.

Berdasarkan data, dapat diketahui jawaban responden variabel Y (Pilihan Karir) mempunyai skor minimum 9,26 dan skor maximum 22,09, rata-rata 14,9103, standar deviasi 3,27518 . Standar deviasi merupakan suatu ukuran penyimpangan. Jika nilainya kecil maka data yang digunakan mengelompok disekitar nilai rata-rata, nilai variance 10,727 yang berarti tingkat penyebaran data normal, atau data sangat heterogen. 


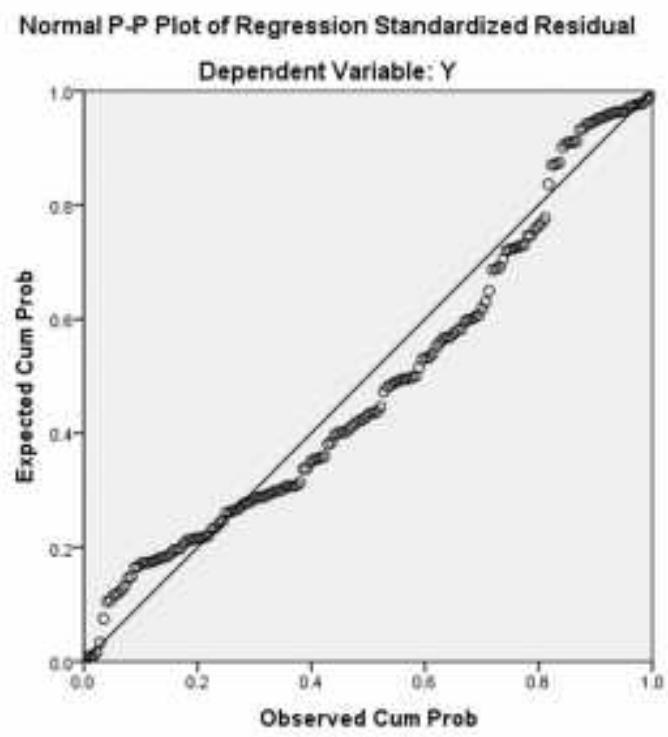

Gambar 1. Hasil Uji Normalitas Regresi Berganda

Dari gambar diatas terlihat bahwa titik-titik tersebut tersebar mendekati garis diagonal dan mengikuti garis diagonal, ini membuktikan bahwa model regresi ini telah memenuhi asumsi normalitas. Dengan hasil diatas dapat dikatakan bahwa model yang dibuat merupakan model yang valid dan dapat dipergunakan untuk analisis selanjutnya yaitu regresi berganda

Berdasarkan pada hasil output SPSS uji Kolmogorov - Smirnov, nilai Asymp.Sig (2 tailed) sebesar 0,160, nilai tersebut memenuhi ketentuan sig (p) >0,05 (level of signification). Jadi hipotesis Ho diterima, sedangkan hipotesis Ha ditolak, berarti data residual berdistribusi normal.

Berdasarkan output SPSS dapat diketahui nilai VIF kelima variabel, yaitu Minat (X1), Motivasi (X2), Pelatihan Profesional (X3), Gender (X4), Lingkungan Pekerjaan (X5). Dari kelima variabel tersebut maka dapat disimpulkan bahwa VIF kurang dari 10 dan Tolerance melebihi 0,1 maka model regresi terbebas dari multikolinearitas.

(Suyono, 2014), Uji Korelasi bertujuan untuk menguji hubungan antara dua variabel yang tidak menunjukan hubungan fungsional (berhubungan bukan berarti disebabkan).

Koefisien Korelasi memiliki nilai antara -1 hingga +1 . Sifat nilai koefisien korelasi adalah plus (+) atau minus (-). Hal ini menunjukan arah korelasi. Makna sifat korelasi :

1. Korelasi positif $(+)$ berarti jika variabel $X_{1}$ mengalami kenaikan maka variabel $X_{2}$ juga akan mengalami kenaikan, atau jika variabel $X_{2}$ mengalami kenaikan maka variabel $\mathrm{X}_{1}$ juga akan mengalami kenaikan.

2. Korelasi (-) berarti jika variabel $X_{1}$ mengalami kenaikan maka variabel $X_{2}$ akan mengalami penurunan, atau jika variabel $\mathrm{X}_{2}$ mengalami kenaikan maka variabel $\mathrm{X}_{1}$ mengalami penurunan.

Sifat Korelasi akan menentukan arah dari korelasi. Keeratan korelasi dapat dikelompokan sebagai berikut:

1. 0,00 sampai dengan 0,20 berarti korelasi memiliki keeratan sangat lemah.

2. 0,21 sampai dengan 0,40 berarti korelasi memiliki keeratan lemah.

3. 0,41 sampai dengan 0,70 berarti korelasi memiliki keeratan kuat.

4. 0,71 sampai dengan 0,90 berarti korelasi memiliki keeratan sangat kuat.

5. 0,91 sampai dengan 0,99 berarti korelasi memiliki keeratan sangat kuat sekali.

6. 1 berarti korelasi sempurna. 
Interprestasi atas hasil uji korelasi :

A. Variabel Minat $\left(\mathrm{X}_{1}\right)$ dan Pilihan Karir $(\mathrm{Y})$

a. Nilai Pearson Correlation sebesar $-0,015$, berarti terdapat korelasi yang memiliki keeratan sangat lemah antara variabel $\mathrm{X}_{1}$ dan $\mathrm{Y}$

b. Korelasi bersifat negatif/tidak searah $(-0,015)$

c. Korelasi tidak signifikan $(\mathrm{sig}=0,851>0,05)$

Hal ini dapat dikatakan bahwa minat seseorang tidak cenderung dapat menjadi faktor yang mempengaruhi pilihan karir dimana hal ini dikatakan dalam penelitian ini dimana minat memiliki korelasi negative dan tidak memiliki hubungan yang signifikan.

B. Variabel Motivasi $\left(\mathrm{X}_{2}\right)$ dan Pilihan Karir $(\mathrm{Y})$

a. Nilai Pearson Correlation sebesar 0,040 , berarti terdapat korelasi yang memiliki keeratan sangat lemah antara variabel $\mathrm{X}_{2}$ dan $\mathrm{Y}$

b. Korelasi bersifat positif/searah $(0,040)$

c. Korelasi tidak signifikan $(\mathrm{sig}=0,612>0,05)$

Motivasi diperlukan dalam memilih pilihan karir dimana motivasi ini memiliki hubungan yang positif namun tidak memiliki korelasi yang signifikan, dikarenakan motivasi seseorang tidak terlalu dibutuhkan dalam melakukan pemilihan karir, karena banyak dari mahasiswa baru sudah mencoba untuk menentukan pilihan karirnya sendiri tanpa bantuan dari orang lain.

\section{Variabel Pelatihan Profesional $\left(\mathrm{X}_{3}\right)$ dan Pilihan Karir (Y)}

a. Nilai Pearson Correlation sebesar $-0,068$, berarti terdapat korelasi yang memiliki keeratan sangat lemah antara variabel $\mathrm{X}_{3}$ dan $\mathrm{Y}$

b. Korelasi bersifat negatif/tidak searah $(-0,068)$

c. Korelasi tidak signifikan $(\mathrm{sig}=0,387>0,05)$

Pelatihan professional memiliki hubungna yang negative dan tidak memiliki hubungan yang signifikan hal ini berarti bahwa pelatihan professional tidak terlalu dibutuhkan dalam melakukan pemilihan karir, dimana banyak mahasiswa lulusan baru/fresh graduate dapat memulai pekerjaan walau tidak memiliki keterampilan khusus.

D. Variabel Gender $\left(\mathrm{X}_{4}\right)$ dan Pilihan Karir (Y)

a. Nilai Pearson Correlation sebesar 0,139 , berarti terdapat korelasi yang memiliki keeratan sangat lemah antara variabel $\mathrm{X}_{4}$ dan $\mathrm{Y}$

b. Korelasi bersifat positif/searah $(0,139)$

c. Korelasi tidak signifikan ( $\operatorname{sig}=0,079>0,05)$

Variabel gender memiliki hubungan yang positif hal ini berarti gender memiliki hubungan dalam pemilihan karir, dimana gender ini sangat berpengaruh dalam memulai karir didunia kerja, hal ini dapat dibuktikan bahwa kebanyakan gender pria melakukan pekerjaan yang lebih berat dibandingkan dengan gender wanita,

E. Variabel Lingkungan Pekerjaan $\left(\mathrm{X}_{5}\right)$ dan Pilihan Karir (Y)

a. Nilai Pearson Correlation sebesar 0,209, berarti terdapat korelasi yang memiliki keeratan sangat lemah antara variabel $\mathrm{X}_{5}$ dan $\mathrm{Y}$

b. Korelasi bersifat positif/searah $(0.209)$

c. Korelasi signifikan $(\operatorname{sig}=0,008<0,05)$ 
Lingkungan pekerjaan memiliki faktor hubungan yang signifikan dan berpengaruh positif, hal ini dapat dikatakan bahwa lingkungan pekerjaan memang memiliki faktor dalam mempengaruhi pilihan karir. Dimana banyak dari mahasiswa ingin memilih pekerjaan yang tidak terlalu berat dalam memulai karirnya.

Model Summary

\begin{tabular}{ccccc}
\hline Model & $\mathbf{R}$ & $\begin{array}{c}\mathbf{R} \\
\text { Square }\end{array}$ & $\begin{array}{c}\text { Adjusted } \\
\text { R Square }\end{array}$ & $\begin{array}{c}\text { Std. Error } \\
\text { of the } \\
\text { Estimate }\end{array}$ \\
\hline 1 & $.271^{\mathrm{a}}$ & .073 & .044 & .20076 \\
\hline a. Predictors: (Constant), X5, X1, X3, X4, X2
\end{tabular}

Angka Adjusted $R$ Square sebesar 0,044, artinya sebesar 4,4\% (0,044 x 100\%) dari variabel pilihan karir diatas dijelaskan oleh variabel minat, motivasi, pelatihan professional, gender, dan lingkungan pekerjaan. Sisanya sebesar 95,6\% dijelaskan oleh variabel lain selain kelima variabel independen dalam penelitian ini.

\section{KESIMPULAN}

Setelah dilakukan penelitian, maka diperoleh hasil analisis terhadap hipotesa pertama, kedua, ketiga, keempat, kelima, dan keenam sebagai berikut :

Minat tidak berpengaruh secara signifikan terhadap pilihan karir akuntan publik dan non publik, motivasi tidak berpengaruh secara signifikan terhadap pilihan karir akuntan publik dan non publik, pelatihan Profesional tidak berpengaruh secara signifikan terhadap pilihan karir akuntan publik dan non publik, gender berpengaruh secara signifikan terhadap pilihan karir akuntan publik dan non publik, lingkungan Pekerjaan berpengaruh secara signifikan terhadap pilihan karir akuntan publik dan non publik, minat,

Motivasi, Pelatihan Profesional, Gender, dan Lingkungan Pekerjaan berpengaruh secara bersama-sama dan signifikan terhadap pilihan karir akuntan publik dan non publik

\section{PENUTUP}

\section{Keterbatasan Penelitian}

Penelitian ini memiliki keterbatasan-keterbatasan yang berkemungkinan menimbulkan gangguan terhadap hasil penelitian. Data yang dianalisis dalam penelitian ini akan menimbulkan masalah jika persepsi responden berbeda dengan keadaan yang sesungguhnya. Penelitian ini hanya menerapkan metode penyebaran kuisioner dan tidak menerapkan metode lainnya seperti wawancara atau metode lainnya. Data yang telah diolah dalam kuisioner ini adalah data yang objektif disebabkan waktu penyebaran yang terbatas dan factor kenyamanan para responden dalam pengisian merupakan kendala yang belum diperhatikan secara maksimal.

\section{Saran}

Peneliti menyarankan agar peneliti selanjutnya dapat menambah variabel-variabel bebas lainnya yang memiliki kemungkinan adanya pengaruh terhadap pilihan karir akuntan publik dan non publik selain variabel-variabel yang dilakukan didalam penelitian ini, agar dapat memperoleh hasil yang lebih maksimal, variabel-variabel yang ditambah mungkin bias seperti penghargaan finasial, pengakuan professional, dll. Disarankan untuk memperbanyak jumlah responden dan universitas yang akan diteliti karena dengan semakin banyak jumlah responden dan universitas akan mempengaruhi hasil penelitian agar hasil nya lebih akurat. 


\section{DAFTAR PUSTAKA}

Andersen, W. (2012). Analisis Persepsi Mahasiswa Akuntansi Dalam Memilih Profesi Sebagai Akuntan.

Djaali, \& M. (2007). Pengukuran Dalam Bidang Pendidikan. Jakarta: Grasindo.

Gunawan, Aprilia., R. W. (2014). Jurnal Faktor-Faktor Yang Mempengaruhi Pilihan Karir Mahasiswa Akuntansi Sebagai Akuntan Publik, General Accountant, Dan Non Akuntan. Tax \& Accounting, 4.

Jumamik. (2007). Persepsi Mahasiswa Akuntansi Mengenai Faktor-Faktor yang Mempengaruhi Pemilihan Karir Akuntan.

Rahayu, S. (2011). Sumber : SNA VI, Sri Rahayu.

Rivai, V. (2004). Manajemen Sumber Daya Manusia Untuk Perusahaan (1st ed.). PT. Raja Grafindo Persada.

Sandjaja, B.,\&Heriyanto, A. (2006). Panduan Penelitian. Jakarta: Prestasi Pustaka.

Siagian, S. (2008). Filsafat Administrasi. Jakarta: Bumi Aksara.

Slameto. (2003). Belajar dan Faktor-faktor yang Mempengaruhinya. Jakarta: Rineka Cipta.

Sri Rahayu, Eko Arief S, D. S. (2003). Persepsi Mahasiswa Akuntansi Mengenai FaktorFaktor Yang Mempengaruhi Pemilihan Karir. Simposium Nasional.

Stephen P. Robbins, Timothy A. Judge, B. M. (2009). Organizational Behavior (13th ed.).

Stephen P. Robbins, Timothy A. Judge, B. M. (2011). Organizational Behaviour. Australia: Corporate Culture.

Suyono, N. A. (2014). Analisis Faktor-faktor yang Mempengaruhi Pemilihan Karir Sebagai Akuntan Publik (Studi Empiris pada Mahasiswa Akuntansi Unsiq). Jurnal PPKM, II, 69-83.

Wijayanti. (2003). Faktor-Faktor yang Mempengaruhi Pemilihan Karir Mahasiswa Akuntansi di Yogyakarta. Riset Akuntansi Indonesia, 3(2). 